DOI:10.22337/2587-9618-2018-14-3-103-113

\title{
ABOUT THE PROBLEM OF ANALYSIS RESISTANCE BEARING SYSTEMS IN FAILURE OF A STRUCTURAL ELEMENT
}

\author{
Anatoly V. Perelmuter ${ }^{1}$, Oleg V. Kabantsev ${ }^{2}$ \\ ${ }^{1}$ SCAD Soft Ltd, Kyiv, UKRAINE \\ ${ }^{2}$ National Research Moscow State University of Civil Engineering, Moscow, RUSSIA
}

\begin{abstract}
This paper focuses on the methods of calculating load-bearing systems in the case of a failure of a structural element. This kind of failure makes it necessary to assess further behavior of the structure with a possibility of the progressive collapse development. The stress-strain state analysis of a load-bearing system in the case of a failure of a structure is carried out by two main methods - static and dynamic calculation. It is shown that the static calculation (quasi-static analysis using the dynamic amplification factor) is not a universal method. This paper justifies the application of the direct dynamic calculation in the mode of direct integration of motion for the design analysis of load-bearing systems with high rigidity stories (protection structures for a load-bearing system). It also gives recommendations for selecting parameters of the direct dynamic calculation in the case of a failure analysis of a bearing structure.
\end{abstract}

Keywords: modeling, numerical methods, calculation model, strain-stress state, progressive collapse

\section{ОБ АНАЛИЗЕ СОПРОТИВЛЕНИЯ НЕСУЩИХ СИСТЕМ ПРИ ОТКАЗЕ КОНСТРУКТИВНОГО ЭЛЕМЕНТА}

\author{
А.В. Перельмутер ${ }^{1}$, О.В. Кабанцев ${ }^{2}$ \\ ${ }^{1}$ НПО СКАД Софт, г. Киев, УКРАИНА \\ ${ }^{2}$ Национальный исследовательский Московский государственный строительный университет, \\ г. Москва, РОССИЯ
}

\begin{abstract}
Аннотация: Рассматриваются вопросы методики расчета несущих систем при отказе конструктивного элемента. Отказ такого рода приводит к необходимости оценить дальнейшее поведение конструкции с возможностью развития прогрессирующего разрушения. Анализ напряженно-деформированного состояния (НДС) несущей системы в условиях отказа конструкции выполняется по двум основным методикам статический и динамический расчет. Показано, что статический расчет (квазистатический анализ с использованием коэффициента динамичности) не является универсальным методом. Приведены обоснования того, что для расчетного анализа несущих систем с этажами повышенной жесткости (конструкции защиты несущей системы) целесообразно применять прямой динамический расчет в режиме прямого интегрирования движения. Приведены рекомендации по выбору параметров прямого динамического расчета при анализе отказа несущей конструкции.
\end{abstract}

Ключевые слова: моделирование, численные методы, расчетная модель, напряженно-деформированное состояние, прогрессирующее обрушение

\section{INTRODUCTION AND TASK STATEMENT}

Stability evaluation of the load-bearing system in the event of individual load-bearing structure failure or when a local defect is created in the structural system is one of the most important tasks when assessing the safety level of the building bearing system in its entirety. In some cases, this task is formulated as an estimate of the structure survivability $[1,2,3]$ which seems to be one of the justified approaches. The legislative document in force [4] outlines requirements to ensure mechanical safety of buildings and structures in the event of an emergency design situation: 
'when designing a facility of an increased criticality rating, an emergency design situation must also be taken into account, which has a low chance of appearance and short-term duration, but ... which is crucial from the point of view of the consequences of reaching the limit states that may be generated in this situation (including the limit states arising in connection with explosion, collision, emergency situation, fire, and also right after the failure of one of the supporting structures)'.

Following further description of the requirements [4], the state standard [5] outlines the requirements with regard to the stress-strain forecast of the bearing systems: 'When performing structural design, the following design situations should be taken into account: 'emergency' being a situation which implies exceptional conditions of the building operation and which can lead to significant social, environmental and economic losses'. The state standard [5] introduces a new kind of limit state: 'special limit states, namely the states arising from particular impacts and situations exceeding of which leads to the failure of structures with disastrous consequences'. It should be mentioned that previously the regulatory documents did not cover 'special limit states'.

The definition of special effect sis thoroughly studied in the regulatory document [6], where in the definition is follow sis given: 'Special loads are those loads and impacts (e.g., explosion, collision with vehicles, equipment failure, fire, earthquake, certain climate-relevant impact, failure of a structural element) which result in emergency situations with eventual catastrophic consequences'. Code of Practice [6] defines that' the impact caused by particular emergency effects needs to be taken into account in modeling to determine the structures progressive collapse. Along with the wording of the aforementioned state standard [5], the following is defined: 'Calculation model for the structures progressive collapse may be considered not compulsory if special measures are ensured and which exclude progressive collapse of the structure or part thereof'.
The standard [5] requires as follows: 'For every limit state there should be taken into account the design models of the structure, its structural elements and bases which can characterize their behavior under the most unfavorable conditions at the time of their construction and operation.

As a matter of fact, evaluation of the bearing system resistance in the event of failure of the structural element can be reduced to an analysis of the development of fracture processes in the bearing system due to a local cause (failure of an individual structural unit). This approach corresponds to the modern interpretation of the well-known and frequently used concept of $\mathrm{a}^{6}$ progressive collapse' which is considered to be a' disproportional' destruction owing to a local failure. It seems that the term 'disproportional' in view of destruction more closely corresponds to a phenomenon that the norms require to prevent, namely: it is deemed compulsory to avoid advancement (development) of destructions in the bearing system due to occurrence of the initial failure of an individual structural unit.

To evaluate the bearing system resistance against a local structural failure, various methods are proposed. For instance, in [7] it is proposed to employ the survivability index $I_{R C}$ :

$$
I_{R C}=\frac{R_{\max }-R}{R_{\max }}
$$

where $R_{\max }$ is the maximum possible failure; $R$ is the failure caused.

The source [8] thus defines the quantitative index of survivability $K$ :

$$
K=\frac{\sum_{i=1}^{m} k_{i}\left(N_{i}-n_{i}\right)}{\sum_{i=1}^{m} N_{i}}
$$

where $N_{i}$ is the total of the structural elements in this group; $m$ is the total of the groups of elements; $k_{i}$ is the weight factor for $i$-th of the group of elements; $n_{i}$ is the total of the damaged elements of the $i$-th group. 
It should be noted that the proposed methods of resistance of the bearing system (evaluation of 'survivability' as the terminology proposed by the authors) imply the information on the extent of destruction. In order to estimate the survivability of the designed buildings using the methods as above, a forecast of the extent of damage needs to be carried out and which can be supported by the outcome of the design analysis.

Information on the extent of destruction that occurred and was caused by the initial local failure is also needed to assess the correspondence of such an extent to the maximum admissible values of the destruction in the building (structure) which are outlined by the norms [6] (Item 5.7):

'Under the action of design and emergency specific circumstances, the maximum allowable area of local destruction of the load-bearing structures is determined as follows:

- for buildings with height of less than $75 \mathrm{~m}$ it is up to $40 \mathrm{~m}^{2}$;

- for buildings with height of 75 to $200 \mathrm{~m}$ it is up to $80 \mathrm{~m}^{2}$;

- for buildings with height of more than $200 \mathrm{~m}$ it is up to $100 \mathrm{~m}^{2}$;

- for other facilities it is determined by the design brief and depends on the structure type (large-span shells, bridges, cooling towers, air-discharge pipes, etc.).

Thus, the task of the calculation model of the bearing system in the absence of a local structural element to provide a consistent result (namely the process of development or neutralization of the development of destructions and the scope of destroyed elements) is by all means important from the point of view of implementation of the requirements of the existing laws and regulations. It should be emphasized that the contemporary best practice of designing the load-bearing systems provides an approach which proves to be not entirely justifiable to allow the formation of such significant 'allowable' degrees of structural damage (re. Item 5.7 [6]). In order to block the development of the destruction caused by the initial local event, various types of 'special measures excluding the progressive collapse of the structure or part thereof ([5]) or ' $\ldots$ measures limiting the destruction area ([6])' are proposed. For instance, the source [9] suggests one method of protection against progressive collapse based on the arrangement of floors of increased stiffness (outrigger floors) and which ensure certain modification in the operation pattern of the vertical load-bearing structure in the event of failure of a lower-lying element; such structural unit is suspended to an outrigger floor. The principle of operation of the outrigger floor as a structure providing for the 'suspension' of vertical bearing structures is quite consistent with the definition of 'a special measure excluding progressive collapse of the structure or part thereof' which causes its extensive practical use when designing high-rise reinforced concrete buildings.

As the above mentioned concise analysis of the issues of estimating the resistance of a load-bearing building system in event of failure of the individual load-bearing structural units shows that the most important element ensuring the possibility to forecast the behavior of the bearing system, as well as assessing the compliance of the system with the regulatory requirements, represents the method of calculating of the bearing system under the special design situation. This method of calculation should ensure that the particularities of the processes occurring in the bearing system are taken into account when the bearing element locally fails and this requires the implementation of a number of special numerical methods.

\section{ANALYSIS OF METHODS TO CALCULATE BEARING SYSTEMS IN THE EVENT OF LOCAL STRUCTURAL FAILURE}

In line with the established practice of design analysis of load-bearing systems in the special design situation, two cases of failure of local design can be considered:

a) the structural element is not included into the operation of the bearing system due to external causes: failure to complete the design solution of the node (absence of bracing elements, unacceptable plays and clearances, 
etc.); structural material not envisioned by the design brief (when mixing concrete mortar low-quality or defective cement is used); nonfulfillment of the design solution for the structural element (underestimated longitudinal / transverse reinforcement, low-quality rolled products profile is used);

b) the structural element is included into the operation of the bearing system structure; still owing to some external impact it gets destroyed and loses its bearing capacity.

Case (a) corresponds to a design model which features no defective structure, and this leads to the formation of an adequate stress-strain state for this kind of a bearing system in its entirety. Case b) illustrates a more complicated situation; therein should be considered several stages of existence of a calculation model of the bearing system:

1. A calculation model corresponding to the design state with a full set of structural elements and formed stress-strain state;

2. A calculation model corresponding to the changed state of the bearing system (without a failure of a structural element), which leads to alteration of the original stress-strain state and, consequently, may lead to subsequent (secondary) destructions of the bearing system elements;

3. A calculation model corresponding to the modified state of the bearing system with consideration for secondary destructions which also lead to alteration of the original stressstrain state formed at stage 2, and, consequently, may lead to further subsequent destructions of the bearing system elements.

Thus, the failure of the load-bearing structure in case (b) predetermines the need for a multi-stage design analysis accounting for the inherited stress-strain state from stage to stage. Calculation techniques for a multi-stage design analysis should provide an accurate solution to the problem under the conditions of stiffness degradation in individual elements of the design model; similar questions of multi-stage calculations are considered in the source [10].
The most important provision in the event of failure of the bearing structure in view of the design analysis in case (b) is the possibility to correctly consider the mechanism of 'removal' of the stressed-strained element out of the design model composition, which leads to the formation of a certain dynamic effect. It is certain that problems of this sort can be successfully solved within the process of a direct dynamic calculation (when it comes to the field construction, the modules of direct dynamic calculation are included in all the main computational software). Nonetheless, the direct dynamic calculation technique is quite comprehensive, and requires generation of a variety of special raw data inclusive of the structural materials performance characteristics under dynamic influences, etc.

For the purposes of impact mitigation in the direct dynamical modeling problems it is proposed to employ the quasi-static calculation method using the $k_{d}$ dynamic factor (see, for instance, sources $[11,12])$. By virtue of its simplicity, the calculation based on the dynamic factor usage has gained popularity. It is due in no small part to the fact that for a system with one degree of freedom which is acted upon by a short-time loading the values of the dynamic coefficient [13] and its ceiling limit $\left(k_{d}=2\right)$ are known.

It is known that making a quasi-static calculation with the account for the dynamic coefficient is justified only for systems with one degree of freedom when this coefficient is defined as a ratio of displacements triggered by the same load at its dynamic and static actions (Figure 1).

When it comes to multi-element systems, quite good results can be obtained in those cases when the system motion mode is close to the form of its static equilibrium without a remote element. Only then one can discuss the ratio of displacements common to all nodes of the system. 


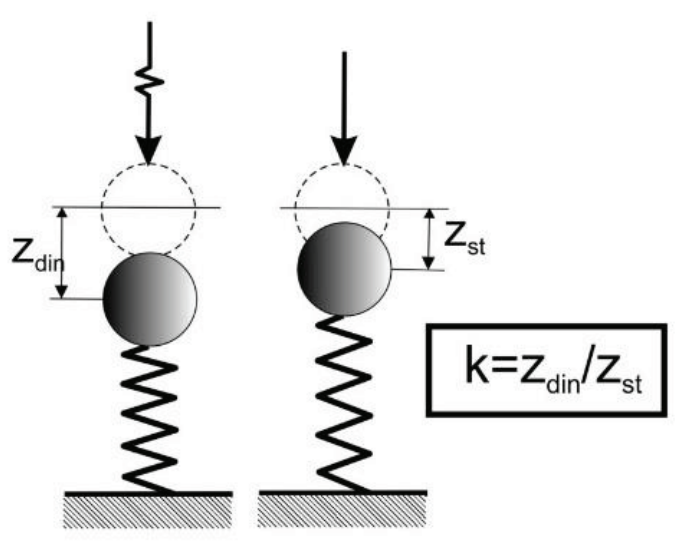

Figure 1. Determination of dynamic coefficient.

In critical cases it is natural to check the dynamic behavior of the system. This can be achieved and illustrated by means of a simplified model of a truss (Figure 2) which is studied in the sources $[14,15]$.

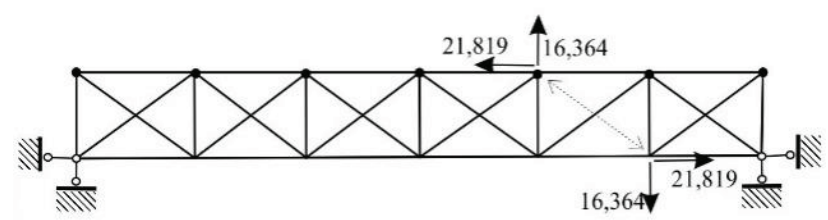

\section{Figure 2. Design model to illustrate the example.}

The truss elements are made of square pipes: belts $160 \times 5$, braces $140 \times 5$, racks $80 \times 5$. The main weight is assumed to be concentrated in the upper nodes of the truss; the weights are shown in Figure 2.

Based on the static loading of the truss with all elements in the diagonal rod of 6-12, the force value equals to $\mathrm{N}=27,274 \mathrm{t}$.

If the truss is studied with no consideration of the diagonal rod of 6-12, in order to restore the static equilibrium for the nodes of 6 and 12 of the finite element model, it is compulsory to apply the load equal to the force acting in this diagonal rod. In Fig. 3 such a load is represented by means of components directed along coordinate axes. In this case (units of measurement are tons) the following is valid:

$$
N=27,274=\sqrt{16,362^{2}+21,819^{2}}
$$

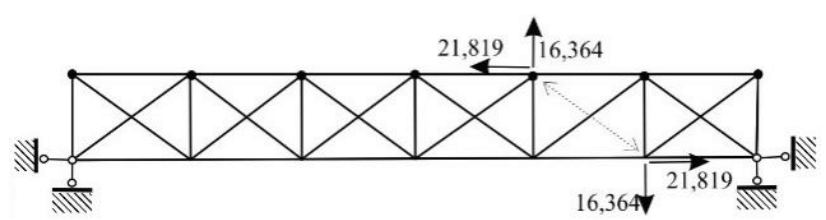

Figure 3. Elements replaced by reactions.

The physical withdrawal of the diagonal rod 6-12 is associated with a sudden (very rapid) dump of the loads shown in Figure 3 which in the calculation model is implemented by generation of a new load with the forces directed in opposite directions (Figure 4) and which increase in time from zero (at the beginning of the loading process) to their full value.

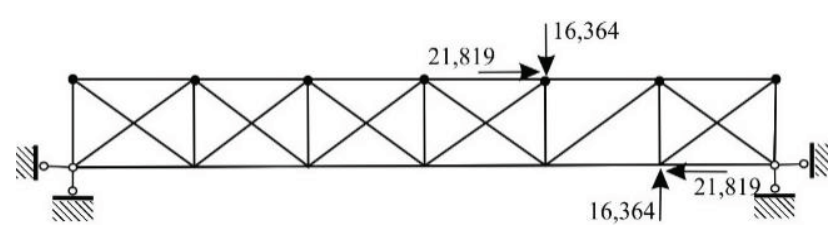

Figure 4. Impact from the element withdrawal.

In theory, the pattern of time variation of this conditional loading should be established by trial and error, and can be different for different forces; still taking into account the high failure rate, the connection can be assumed as a piecewise linear one and remaining identical for all forces.

Hence, it is essential to make a dynamic calculation to assess the forces arising from a sudden removal of the element. In this case, the dynamic effect can be described by the bilinear time-dependent forces (Figure 5) where $t_{d}$ is the failure time during which the structure once received a 'negative impulse' at first 'gets stuck' in its initial position due to the inertia forces and then starts to move yet in a defective state.

The solution to the problem is found using the SCAD software complex [16] performing in the Direct motion integration mode. At that, the required procedural modeling is carried out in accordance with the requirements of the design mode: a special static load is gained, a file describing the law on variation of forces arising from the sudden removal of an element is generated, a value of the modal damping action is specified, integration spacing $(0.01 \mathrm{sec}$.) is recorded a well as the action period $(2 \mathrm{sec}$.$) .$ 


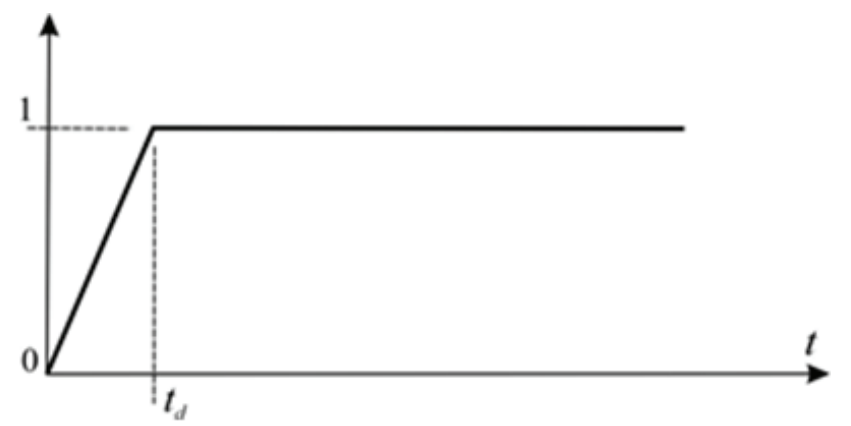

Figure 5. Time-depended load increase (force $P$ is given on the vertical axis).

In order to analyze the state of the elements of the structural design, it is prerequisite to consider the graphs illustrating the change in forces in the elements. SCAD features this function in the query mode to obtain data on an element (Figure 6 can be referred to as an example).

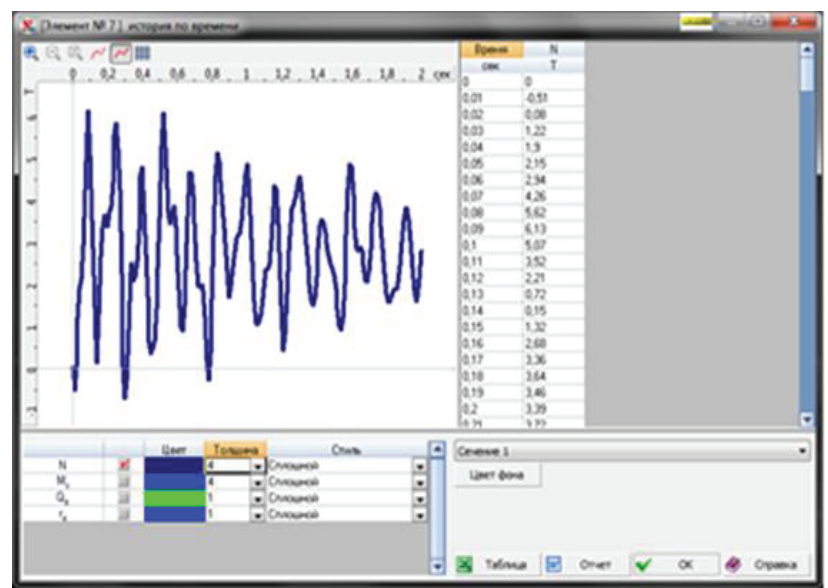

Figure 6. Track record on time-dependent change in force in the design model elements.

The stress-strain analysis of the elements of the model in time shows that the utmost force values generated in the elements of the system (as well as the movements of the nodes) are not achieved simultaneously (for reference see an example of the change in forces in individual elements in Figure 7). Thus, in element 8 the extremum is reached at time $\mathrm{t}=0.21 \mathrm{sec}$., in element 11 at $\mathrm{t}=0.17 \mathrm{sec}$., and in elements 20 and 31 at $\mathrm{t}=0.16 \mathrm{sec}$.

Likewise, it should be taken into account that all motions of the system occur around the displaced equilibrium which was gained by the structure at the moment preceding the element destruction. Therefore, the results of the dynamic calculation obtained at direct integration of the equations of motion should be added up with the results of a static calculation of an intact structure.

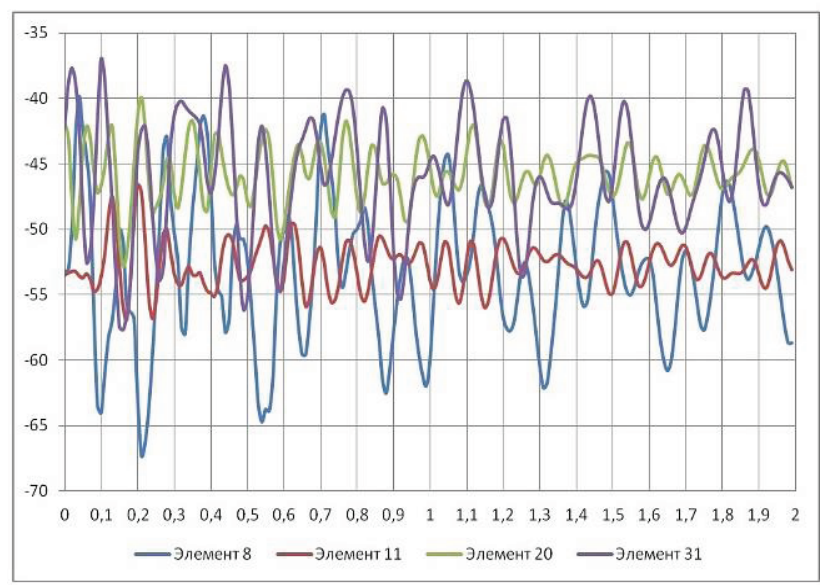

Figure 7. Time-dependent change in forces for some elements of the design model.

The research problem to study the stress-strain state of the design model elements as shown in Figure is also solved in quasi-static mode employing the dynamic factor $k_{d}=2.0$ (at the utmost theoretical value). Correlated values of the solution results obtained through various methods are given in Table 1.

Juxtaposition of the obtained results with the numerical method in [15] proves good agreement of results. When it comes to the quasi-static solution obtained employing the dynamic factor $k_{d}=2.0$, strong divergence gets to the surface. Such fundamental difference in results can be explained through the incongruity of the static equilibrium model form without a removed element and the first form of self-induced oscillations (Figure 8). Thus, the very concept of dynamic factor as a multiplier to the static deformation bears no significance. It should be noted that the idea of a quasi-static calculation employing the dynamic factor and based on the energy approach (ref. [11]), is widely used by various authors in view of the structures made of materials in which the stress-strain state is not linear. At that, the researchers of the stress-strain state for the bearing system in the mode of failure of its individual elements highlight that if there is inelastic deformation detected in the construction material (and 
About the Problem of Analysis Resistance Bearing Systems in Failure of a Structural Element

Table 1. Correlated values of the solution results obtained through various methods.

\begin{tabular}{|c|c|c|c|c|c|c|}
\hline \multirow[t]{2}{*}{$\begin{array}{c}\text { \# of } \\
\text { element }\end{array}$} & \multicolumn{4}{|c|}{ Forces in element } & \multicolumn{2}{|c|}{$\begin{array}{c}\text { Divergence of results } \\
\text { through SCAD }(\%)\end{array}$} \\
\hline & $\begin{array}{l}\text { Intact } \\
\text { system }\end{array}$ & $\begin{array}{c}\text { Dynamics } \\
{[15]}\end{array}$ & $\begin{array}{l}\text { Dynamics } \\
\text { [SCAD] }\end{array}$ & $\begin{array}{c}\text { Quasi-statics } \\
k_{d}=2,0\end{array}$ & $\begin{array}{l}\text { vs. the } \\
\text { results of } \\
{[15]}\end{array}$ & $\begin{array}{l}\text { vs. the results } \\
\text { ofquasi- } \\
\text { statics } k_{d}=2,0\end{array}$ \\
\hline $1-2$ & $-28,778$ & $-36,21$ & $-36,404$ & $-20,116$ & 0,54 & 44,74 \\
\hline $2-3$ & 4,862 & 18,18 & 18,539 & 13,717 & 1,97 & 26,01 \\
\hline $3-4$ & 23,916 & 34,86 & 34,676 & 31,932 & $-0,53$ & 7,91 \\
\hline $4-5$ & 23,916 & 35,03 & 35,597 & 39,712 & 1,62 & $-11,56$ \\
\hline $5-6$ & 4,862 & $-20,29$ & $-19,869$ & $-52,084$ & $-2,07$ & $-162,14$ \\
\hline $6-7$ & $-28,778$ & $-30,66$ & $-30,203$ & $-13,16$ & $-1,49$ & 56,43 \\
\hline $8-9$ & $-11,822$ & $-18,81$ & $-17,202$ & $-13,094$ & $-8,55$ & 23,88 \\
\hline $9-10$ & $-52,847$ & $-66,68$ & $-67,555$ & $-53,93$ & 1,31 & 20,17 \\
\hline 10-11 & $-71,127$ & $-87,93$ & $-87,725$ & $-73,05$ & $-0,23$ & 16,73 \\
\hline $11-12$ & $-71,127$ & $-80,11$ & $-80,171$ & $-65,271$ & 0,08 & 18,59 \\
\hline $12-13$ & $-52,847$ & $-94,54$ & $-94,811$ & $-119,731$ & 0,29 & $-26,28$ \\
\hline 13-14 & $-11,822$ & $-13,74$ & $-13,983$ & $-6,134$ & 1,77 & 56,13 \\
\hline $1-8$ & $-15,866$ & $-22,18$ & $-22,445$ & $-16,82$ & 1,19 & 25,06 \\
\hline $2-9$ & 7,498 & 12,00 & 12,257 & 5,733 & 2,14 & 53,23 \\
\hline $3-10$ & 5,019 & 7,39 & 7,514 & 2,767 & 1,68 & 63,18 \\
\hline 4-11 & 5,309 & 9,20 & 9,712 & 8,264 & 5,57 & 14,91 \\
\hline $5-12$ & 5,019 & $-19,29$ & $-18,779$ & $-40,75$ & $-2,65$ & $-116,99$ \\
\hline $6-13$ & 7,498 & $-10,22$ & $-10,32$ & $-38,4$ & 0,98 & $-272,09$ \\
\hline $7-14$ & $-15,866$ & $-17,14$ & $-17,244$ & $-11,6$ & 0,61 & 32,73 \\
\hline $1-9$ & $-43,556$ & $-59,77$ & $-59,558$ & $-41,968$ & $-0,35$ & 29,53 \\
\hline $2-8$ & 14,777 & 23,06 & 22,293 & 16,367 & $-3,33$ & 26,58 \\
\hline $2-10$ & $-27,274$ & $-56,63$ & $-54,172$ & $-25,923$ & $-4,34$ & 52,15 \\
\hline $3-9$ & 7,726 & 14,49 & 14,477 & 9,079 & $-0,09$ & 37,29 \\
\hline $3-11$ & $-16,091$ & $-19,99$ & $-20,04$ & $-13,692$ & 0,25 & 31,68 \\
\hline $4-10$ & $-4,424$ & $-8,88$ & $-8,616$ & $-2,023$ & $-2,97$ & 76,52 \\
\hline $4-12$ & $-4,424$ & $-13,38$ & $-14,217$ & $-11,751$ & 6,26 & 17,35 \\
\hline $5-11$ & $-16,091$ & $-24,5$ & $-25,052$ & $-23,415$ & 2,25 & 6,53 \\
\hline $5-13$ & 7,726 & 48,32 & 47,918 & 91,332 & $-0,83$ & $-90,60$ \\
\hline $6-12$ & $-27,274$ & - & - & - & - & - \\
\hline 6-14 & 14,777 & 17,03 & 17,203 & 7,667 & 1,02 & 55,43 \\
\hline $7-13$ & $-43,556$ & $-58,02$ & $-57,717$ & $-50,664$ & $-0,52$ & 12,22 \\
\hline
\end{tabular}

with due regard to their consideration while performing the analysis), the dynamic factor decreases substantially and reaches the value of 1 (for reference see the studies by V.A. Almazov and his students).

The grounds of choosing the quasi-static methods are preconditioned by constant total energy for the element under consideration. Still it must be borne in mind that the total potential energy is a constant for the system in its entirety, and for the multi-element system it is very much likely to observe the shift of this value from one element to another in the process of deformation. In other words, it is not only a system with one degree of freedom, for which the concept of a dynamic factor appears worthwhile but also, on top 
a)
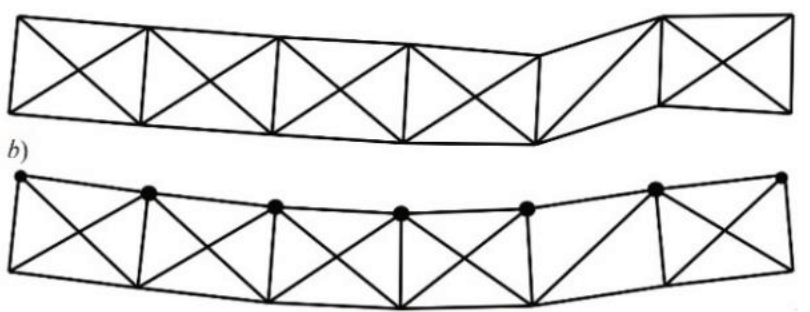

Figure 8. Juxtaposition of the deformation forms: a) static equilibrium form of the model without a removed element; $b$ ) the first form of self-induced oscillations of the model.

of everything, it is also a system with one deformable element.

The use of quasi-static methods for the system analysis which include 'special measures to prevent progressive collapse of the structure or part thereof' [5], e.g., outrigger floors (the overall view is shown in Figure 9), does not in principle enable us to obtain a correct result to be proved by the reasons given above.

\section{Some aspects influencing the selection of time-} dependent load increase.

First of all, this concerns the choice of the failure time $t_{d}$ value. Owing to the ambiguity of this parameter, for structures of the increased criticality rating it is recommended to perform a series of calculations spotting a variation of $t_{d}$ from 0.001 to $0.01 \mathrm{sec}$.

In the American regulatory document [17] it is

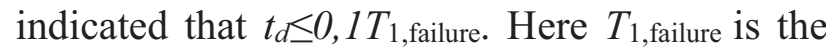
timeline of the initial stage of the self-induced oscillations detected in the failure-impacted design model, namely the design model from which the failed element under consideration has already been removed.

Some foreign sources $[18,19,20]$ recommend considering the general integration time as no less than $0,5 \times T_{1}$,failure. This recommendation arises from the fact that the utmost values of internal forces upon the failure in the majority of cases act till the moment in time calculated as $0,5 \times T_{i}$,

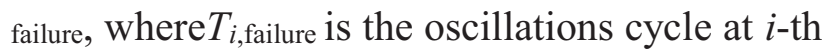
frequency of design model affected by failure in that way of oscillations which is the most proximate to the type of deformation upon the element failure (as per the type shown in Figure 8a).

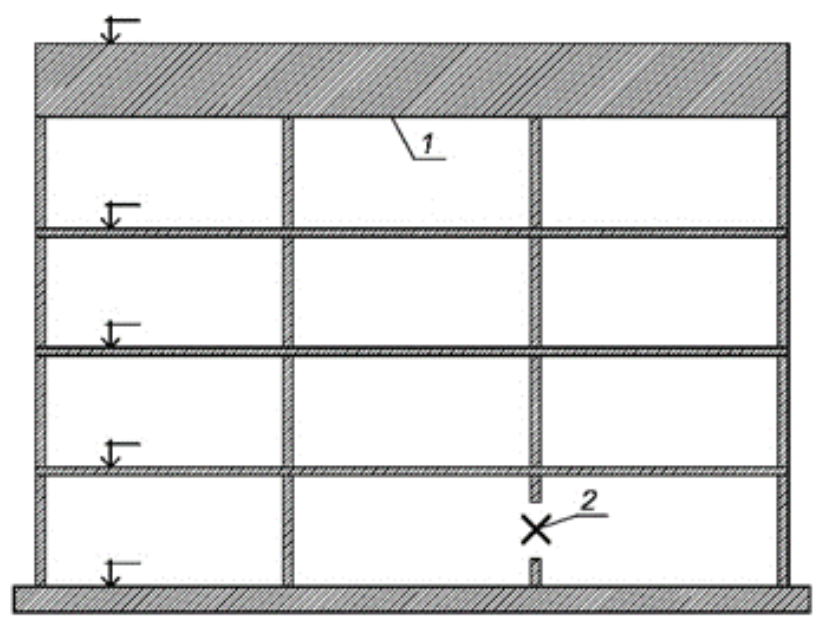

Figure 9. Overall view of the bearing system with outrigger floor: 1 -outrigger floor; 2 - local failure of a structural element.

\section{CONCLUSIONS}

Methods of design analysis of the bearing systems operation in the event of failure of an individual element should accurately account for the processes occurring in actual design. The failure of the local element leads to a realignment of not only the design analysis and the associated forces redistribution, but also results in rather complex dynamic phenomena. The application of simplified methods of the design analysis, i.e. a quasi-static method employing the dynamic factor does not ensure the conditions for modeling accuracy and, thus, the reliability of the design analysis outcome.

\section{REFERENCES}

1. Kolchunov V.I., Klyueva N.V., Androsova N.B., Buchtiyarova A.S. Zhivuchest' zdanii i Sooruzhenii pri Zaproektnykh Vozdeistviiakh [Survivability of Buildings and Structures Under the Impacts Beyond the Design]. Moscow, ASB, 2014, 208 pages. 
2. Klyueva N.V., Korenkov P.A. Metodika Eksperimental'nogo Opredeleniia Parametrov Zhivuchesti Zhelezobetonnykh Ramno-Sterzhnevykh Konstruktivnykh Sistem [Experimental Determination Methods to Define Survivability Criteria for Reinforced Concrete Frame - Rod Structural Systems]. // Nonresidential Industrial and Civil Engineering, 2016, No. 2, pp. 44-48.

3. Bondarenko B.M., Kolchunov V.I. Kontseptsiia i Napravleniia Razvitiia Teorii Konstruktivnoi Bezopasnosti Zdanii i Sooruzhenii pri Silovykh i Sredovykh Vozdeistviiakh [Concepts and Development Trends in the Structural Safety Theory for Buildings and Structures Under the Impact of Stress and Environmental Effects]. // Nonresidential industrial and civil engineering, 2013. No. 2, pp. 28-31.

4. Federal'nyi Zakon "Tekhnicheskii Reglament o Bezopasnosti Zdanii i Sooruzhenii", 30.12.2009, No. 384-FZ [Federal Law No. 384 on Technical Regulations on the Safety of Buildings and Structures].

5. GOST 27751-2014 Nadezhnost' Stroitel'nykh Konstruktsii i Osnovanii. Osnovnye Polozheniia [State Standard GOST 27751-2014 on Reliability of Building Structures and Foundations. Main Provisions].

6. SP 296.1325800.2017 Zdaniia i Sooruzheniia. Osobye Vozdeistviia [Code of Practice SP 296.1325800.2017. Buildings and Structures. Special effects]. Ministry of construction of Russia. Moscow, 2017, 27 pages.

7. Kudishin Yu.I., Drobot D.Yu. Zhivuchest' Stroitel'nykh Konstruktsii - Vazhnyi Faktor Snizheniia Poter' v Usloviiakh Avariinykh Situatsii [Survivability of Structures as a Crucial Factor in Reducing Losses in Emergency Situations]. // Steel structures, 2009, Vol. 15, No. 1, pp. 59-71.

8. Berzhinsky Yu.A., Berzhinskaya L.P. Rezervy Zhivuchesti Bezrigel'nogo Karkasa pri Zaproektnykh Vozdeistviiakh [Survivability Margin of Girdles Frame Work Beyond the Design Impacts]. // Construction in
Seismic-Prone Areas. Buildings Safety. 2013, No. 3, pp. 31-35.

9. Kabantsev O.V. Nekotorye Voprosy Metodiki Normirovanija Raschetov Zhelezobetonnyh Konstrukcij Vysotnyh Zdanij [Some Issues Related to Normalization of Calculations of the Reinforced Concrete Structures of High-Rise Buildings]. // Transregional Public Organization Assistance in Development and Application of Spatial Structures in Construction. Proc. of the scientific session reports, Moscow, 2009, pp. 36-39.

10. Perelmuter A.V., Kabantsev O.V. Uchet Izmeneniia Zhestkostei Elementov $\mathrm{V}$ Protsesse Montazha i Ekspluatatsii [Account of Changes in Stiffness of the Elements in the Course of Assembling and Operation]. // Journal on engineering and construction, 2015, No. 5, pp. 6-14.

11. Geniev G.A. Ob Ocenke Dinamicheskih Jeffektov v Sterzhnevyh Sistemah iz Hrupkih Materialov [On Evaluation of the Dynamic Effect in Rod Systems of Brittle Materials]. // Concrete and reinforced concrete, 1992, No. 9, pp. 25-27.

12. Geniev G.A., Kolchunov V.I., Kluyeva N.V., Nikulin A.I., Pyatikrestovsky K.P. Prochnost' i Deformativnost' Zhelezobetonnyh Konstrukcij pri Zaproektnyh Vozdejstvijah [Strength and Deformation Properties of Reinforced Concrete Structures Beyond the Design Impacts]. Moscow, ASV, 2004, 216 pages.

13. Korenev B.G., Rabinovich I.M. Dinamicheskij Raschet Zdanij i Sooruzhenij (Spravochnik Proektirovshhika) [Dynamic Calculation of Buildings and Structures (Designer manual)]. Moscow, Stroyizdat, 1984, 303 pages.

14. Bondarev Yu.V., Nguen Thankh Suan. Raschet Sterzhnevyh Sistem pri Vnezapnom Udalenii Otdel'nyh Jelementov [Calculation of Rod Systems at Sudden Removal of Individual Elements]. // Construction mechanics and calculation of structures, 2010, No. 4, pp. 43-48. 
15. Potapov A.N., Solomin V.I., Gerbensky A.V., Lemberg E.V. Dinamicheskij Analiz Konstrukcij s Razrushajushhimi Svjazjami [Dynamic Analysis of Structures with Destructive Ties]. // Bulletin of the South Ural State University. Series: Construction and Architecture, 2012, No. 17 (276), pp. 8-12.

16. Karpilovsky V.S., Kriksunov E.Z., Malyarenko A.A., Perelmuter A.V., Perelmuter M.A., Fialko S.U. SCAD Office. Versija 21. Vychislitel'nyj Kompleks SCAD++ [SCAD Office. Version 21. Computational Software SCAD++]. Moscow, SCAD SOFT Publishing House, 2018, 948 pages.

17. GSA Alternate Path Analysis and Design Guidelines for Progressive Collapse Resistance. Washington, DC, General Services Administration, 2013, 127 pages.

18. Fahnestock L., Hoffman S.T. Behavior of Multi-Story Steel Buildings under Dynamic Column Loss Scenarios. // Steel and Composite Structures, 2011, Volume 11, No. 2, pp. 149-168.

19. Gerasimidis S., Baniotopoulos C.C. Disproportionate Collapse Analysis of CableStayed Steel Roofs for Cable Loss. // International Journal of Steel Structures, 2011, Vol. 11, Issue 1, pp. 91-98.

20. Zoli T, Woodward R. Design of Long Span Bridges for Cable Loss. // IABSE Symposium: Structures and Extreme Events. Lisbon, Portugal, September 14-16, 2005, pp. $17-25$.

\section{СПИСОК ЛИТЕРАТУРЫ}

1. Колчунов В.И., Клюева Н.В., Андросова Н.Б., Бухтиярова А.С. Живучесть зданий и сооружений при запроектных воздействиях. - М.: АСВ, 2014. - 208 с.

2. Клюева Н.В., Кореньков П.А. Методика экспериментального определения параметров живучести железобетонных рамно-стержневых конструктивных систем. // Промышленное и гражданское строительство, 2016, №2, с. 44-48.

3. Бондаренко В.М., Колчунов В.И. Концепция и направления развития теории конструктивной безопасности зданий и сооружений при силовых и средовых воздействиях. // Промышленное и гражданское строительство, 2013, №2, с. 28-31.

4. Федеральный закон «Технический регламент о безопасности зданий и сооружений» от 30.12.2009 №384-Ф3.

5. ГОСТ 27751-2014 Надежность строительных конструкций и оснований. Ocновные положения.

6. СП 296.1325800.2017 Здания и сооружения. Особые воздействия. - М.: Министерство строительства и жилищно-коммунального хозяйства Российской Федерации, 2017. - 27 с.

7. Кудишин Ю.И., Дробот Д.Ю. Живучесть строительных конструкций - важный фактор снижения потерь в условиях аварийных ситуаций. // Металлические конструкции, 2009, том 15, №1, с. 59-71.

8. Бержинский Ю.А., Бержинская Л.П. Резервы живучести безригельного каркаса при запроектных воздействиях. // Сейсмостойкое строительство. Безопасность сооружений, 2013, №3, с. 31-35.

9. Кабанцев О.В. Некоторые вопросы методики нормирования расчетов железобетонных конструкций высотных зданий. // Межрегиональная общественная организация «Содействие развитию и применению пространственных конструкций в строительстве»: Тезисы доклада научной сессии. - М., 2009, с. 36-39.

10. Перельмутер А.В., Кабанцев О.В. Учет изменения жесткостей элементов в процессе монтажа и эксплуатации. // Инженерно-строительный журнал, 2015, №1(53), с. 6-14.

11. Гениев Г.А. Об оценке динамических эффектов в стержневых системах из хрупких материалов. // Бетон и железобетон, 1992, №9, c. 25-27. 
12. Гениев Г.А., Колчунов В.И., Клюева Н.В., Никулин А.И., Пятикрестовский К.П. Прочность и деформативность железобетонных конструкций при запроектных воздействиях. - М.: АСВ, 2004. $218 \mathrm{c}$.

13. Коренев Б.Г., Рабинович И.М. Динамический расчет зданий и сооружений (Справочник проектировщика). - М.: Стройиздат, 1984. - 303 с.

14. Бондарев Ю.В., Нгуиен Тханх Суан. Расчет стержневых систем при внезапном удалении отдельных элементов. // Строительная механика и расчет сооружений, 2010, №4(231), с. 43-48.

15. Потапов А.Н., Соломин В.И., Гербенский А.В., Лемберг Е.В. Динамический анализ конструкций с разрушающими связями. // Вестник Южно-Уральского государственного университета. Серия: Строительство и архитектура, 2012, №17(276), с. 8-12.

16. Карпиловский В.С., Криксунов Э.3., Маляренко А.А., Перельмутер А.В., Перельмутер М.А., Фиалко С.Ю. SCAD Office. Версия 21. Вычислительный комплекс SCAD++. - M.: SCAD Софт, 2018. - 948 с.

17. GSA Alternate Path Analysis and Design Guidelines for Progressive Collapse Resistance. Washington, DC: General Services Administration, 2013, 127 pages.

18. Fahnestock L., Hoffman S.T. Behavior of Multi-Story Steel Buildings under Dynamic Column Loss Scenarios. // Steel and Composite Structures, 2011, Volume 11, No. 2, pp. 149-168.

19. Gerasimidis S., Baniotopoulos C.C. Disproportionate collapse analysis of cablestayed steel roofs for cable loss. // International Journal of Steel Structures, 2011, Vol. 11, Issue 1, pp. 91-98.

20. Zoli T, Woodward R. Design of Long Span Bridges for Cable Loss. // IABSE Symposium: Structures and Extreme Events. Lisbon, Portugal, September 14-16, 2005, pp. $17-25$.
Anatoly V. Perelmuter, Foreign member of the Russian Academy of Architecture and Construction Sciences (RAACS), Doctor of Science, Professor; SCAD Soft Ltd; office 1,2, 3a Osvity street, Kiev, 03037, Ukraine; phone: +380442497193 (91), +380442487100, +38044248 80 60; e-mail: avp@scadsoft.com.

Oleg V. Kabantsev, Professor, Dr.Sc., Professor of Department of Reinforced Concrete and Masonry Structures; National Research Moscow State University of Civil Engineering; 26, Yaroslavskoe Shosse, Moscow, 129337, Russia; phone +7 (495) 287-49-14 add 3036, 3084;

E-mail: ovk531@gmail.com.

Перельмутер Анатолий Викторович, иностранный член Российской академии архитектуры и строительных наук (РАAСН), профессор, доктор технических наук; НПО СКАД Софт; 03037, Украина, г. Киев, ул. Просвещения (Освиты), 3а, к. 1,2;

тел.: +380442497193 (91), +380442487100,

+38 04424880 60; e-mail: avp@scadsoft.com.

Кабанцев Олег Васильевич, доктор технических наук, профессор кафедры железобетонных и каменных конструкций, Национальный исследовательский Московский государственный строительный университет; 129337, Россия, г. Москва, Ярославское ш., 26, (SPINкод: 2114-1185); тел. +7 (495) 287-49-14 add 3036, 3084; E-mail: ovk531@gmail.com. 